\title{
Rethinking Participatory Development: A Case for Communicative Ethics
}

\author{
Igbanoi L, Osikhena
}

Master of Arts in Social development Student,, Department of Social Work, University of the Witwatersrand, South Africa

Email: lawlerry2k1@yahoo.com

Victor Chikadzi (PhD)

Lecturer Department of Social Work, University of the Witwatersrand, South Africa

Email: Victor.Chikadzi@wits.ac.za

Doi:10.5901/mjss.2014.v5n14p521

\begin{abstract}
Participatory development has long been touted as a panacea to the development failures resulting from highly burecraticesd and top down development programmes instituted by international donor agencies, governments and local development organisations. Development practitioners see participatory development as putting people at the centre of the development process and involving them in decision-making on initiatives aimed at their progress. Since the popularisation of participatory development in the 1970s, the concept has become a buzzword central to both the theory and practice of development work. However in recent times, participatory development has come under heavy criticism. Not only is the concept plagued with a definitional crises, it has also suffered from methodological shortcomings (Jennings, 2000; Neef, 2003; Mohan, 2001; Cleaver, 1999) that threaten its relevance and usefulness in development work. Arguably, the concept of participatory development is 'dead' and needs a resurrecting. Hinged on the Habermasian principle of communicative action, the paper contends that communicative ethics must be central to the practice of participatory development if we are to rediscover the usefulness and relevance of this practice. The authors argue that interventions in the lives of the poor and marginalised ought to be built on a communicative ethics. This requires moving away from strategic action, which thrives on deception and manipulation, towards genuine involvement of people in development work which affect their circumstances. The discussion contends that this is an imperative without which participatory development will lose its value as an instrument for empowerment in development. The paper begins by giving a brief overview of participatory development and thereafter discusses the Habermasian framework of communicative action. It then proceeds to discuss the evolution of participatory development and thereafter considers the most important critiques that have been levelled against the concept. The final section of the paper proposes communicative ethics as the core ingredient that needs to be embraced in the practice of participatory development for it to regain its worth as a path to the development of the poor and marginalised peoples.
\end{abstract}

\section{Introduction}

Participatory development (hereafter, PD) has for long taken centre stage in development thinking. Understood as a bottom-up approach to development, it is opposed to traditional bureaucratic, top-down programmes and projects that have dominated the development scene (Chambers, 1994 \& 1997; Mohan, 2001; Escobar, 1995; de Campos Guimarães, 2009; Davids et al, 2009; Croft \& Beresford, 1996). The participatory development paradigm maintains that people ought to be at the centre of the development process and must be involved in decision-making about initiatives aimed at their progress. Be that as it may, PD has come under heavy criticism over the last two decades. Apart from a definitional crises and other methodological shortcomings (Jennings, 2000; Neef, 2003; Mohan, 2001; Cleaver, 1999), critics have argued that aims to depoliticise the concept is misguided and have called for its re-politicisation, arguing that the concept cannot gain relevance outside of the political realm (Williams, 2004; de Campos Guimarães, 2009; Mohan \& Stokke, 2000). However, the empowerment question appears to be the greatest critique that has been levelled against PD (Duraiappah, Roddy \& Parry, 2005; Cleaver, 1999), which has led to the conclusion that the concept has lost both its original import and radical nature as a means of enabling poor and marginalised peoples.

Following from the foregoing, this discussion argues that a fundamental problem with PD is that it has continually failed to espouse authentic dialogue with deprived peoples as its way of proceeding. Hinged on the Habermasian principle of communicative action, the paper contends that interventions in the lives of the poor and marginalised ought to be built on a communicative ethics. This requires moving away from strategic action, which thrives on deception and 
manipulation, towards genuine involvement in their circumstances. The discussion contends that this is an imperative or else PD loses its value as an instrument for empowerment in development.

\section{The Habermasian Principle of Communicative Action}

Appreciating PD from the perspective of a communicative ethics follows in the Habermasian framework of communicative action. It is employed in this discussion because the discourse on development that has taken place between the poor and development planners thus far has in many respects been lopsided, top-down, strategic, and ineffective. The Habermasian framework of communicative action can be summed up in the following assumptions: (1) that communicative action is action oriented towards reaching understanding; (2) that choosing strategic action as opposed to communicative action presupposes a desire to act individually; and (3) that practical discourse is embedded in contexts of communicative action, hence a discourse ethics is premised on communicative action (Habermas, 1990; McCarthy, 1978). From these, the principles for authentic dialogue, or genuine participation can be deduced: (a) Every subject with the competence to speak and act is allowed to take part in the discourse; b (i) Everyone is allowed to question any assertion whatever; $b$ (ii) Everyone is allowed to introduce any assertion whatever into the discourse; $b$ (iii) Everyone is allowed to express his or her attitudes, desires, and needs; (c) No speaker may be prevented, by internal or external coercion, from exercising his or her rights as laid down in (a) and (b).

From the foregoing, not only do freedom, equality, dignity, respect and rights come to the fore in the discourse for development but a socio-economic and socio-political dialectic is enacted as people deliberate on their wellbeing collectively. It should be reiterated that communicative action opposes its strategic action counterpart in that while the former seeks to bring all stakeholders into dialogue about developmental issues on a basis of fairness, rationality and a desire to act genuinely, the latter thrives on falsehood, deception and manipulation (McCarthy, 1978). Communicating actively and ethically with the poor and marginalised, therefore, means involving them directly and engaging honestly with them in the processes that impact on their development. The paper suggests that this is an essentiality for governments and other development practitioners otherwise it is of no use to initiate a participatory initiative with the deprived at all.

\section{Overview and Advantages of Participatory Development}

\subsection{Origins of the concept}

PD gained significance in the 1970s as a response to observations that traditional approaches to development did not result in concrete development, significant poverty reduction and empowerment of poor and marginalised peoples (de Campos Guimarães, 2009; Platteau, 2006). The main thrust of the arguments was that, despite the application of various development initiatives to their circumstances, the poor were continually left out of the processes and initiatives directed at meeting their needs (Duraiappah, Roddy \& Parry, 2005; Mohan, 2001; Escobar, 1995; Brohman, 1995; Shah \& Baporikar, 2012). The World Conference of Agrarian Reform and Rural Development (WCARRD) of 1979 in Rome declared that people's participation in institutions that govern their lives is a basic human right (de Campos Guimarães, 2009; Shah \& Baporikar, 2012). Hence, from the 1980s, and through the 1990s, onwards, the general consensus among development agents was that top-down approaches were to be discarded in favour of involving local populations directly in the process of development (Escobar 1995; Brohman, 1995; Pierterse, 2000; Shuurman, 2000; Duraiappah, Roddy \& Parry, 2005; Platteau, 2006; Chambers, 1994; de Campos Guimarães, 2009).

\subsection{Delineating participatory development}

Although PD has progressed steadily through the last three decades, the concept has come to increasingly meant different things to different people (Mohan, 2001; Jennings, 2000; de Campos Guimarães, 2009; Cornwall \& Brock, 2006). Botes and van Rensburg (2000: 41), note that the notion is "one of the most overused, but least understood concepts in developing countries". Its meaning and application, in a theoretical and practical sense, has been difficult to denote in several ways. For example, de Campos Guimarães (2009) and Shah and Baporikar (2012) indicate how diverse interpretations of PD among development consultants, academics, governments and development agencies has resulted in a scenario where the concept lacks an ideology that cuts across all of these interpreters. All of these practitioners define the principles, methods and approaches to PD as it suits their operations and interests. Although Mohan (2001) suggests that the differences in the particular definitions and meanings of the concept ultimately reflect broader goals that PD may achieve, this discussion observes that this diversity of meanings indicates that its application 
to deprived people's circumstances will be arbitrary and will lack ethical measurement. This is so because as long as the concept is unable to gain some standardised understanding across contexts, it may be difficult to measure its impact on deprived people's concrete socioeconomic conditions.

\subsection{Diffusion of the new orthodoxy}

Despite the definitional vagueness that characterises PD, it has become the new canon of development (Williams, 2004; Cornwall \& Brock, 2006; White 1996; Lane, 1995). Couched in the rhetoric of efficiency, empowerment and ownership among other things, this 'act of faith in development' (Cleaver, 1999, 597) has become internalised in the development initiatives of big International Financial Institutions (IFIs) like the World Bank and the International Monetary Fund (IMF), and their International Development counterparts (IDAs) such as the United Kingdom's Department for International Development (DFID) and the United States' Agency for International Development (USAID), among others (Williams, 2004; Cornwall, 2003; Cornwall \& Brock, 2005). Further still, it has become enthroned in state-led development plans and in poverty initiatives like the Poverty Reduction Strategy Papers (PRSPs) introduced in the developing world in the 1990s. This espousal has also extended to both International Non-Governmental Organisations (INGOs) and their local equivalents (NGOs) in the developing world such that no organisation wants to be viewed as being non-participatory. People, then, must always be seen as the drivers of the development process at all times and development agencies must jump on the bandwagon of the participatory rhetoric or forfeit their legitimacy (Cornwall \& Brock, 2006; Mohan, 2001). Without doubt, the enthronement of this belief is essential for government and development organisations in view of criticisms that are continually levelled at development itself, not least from civil society organisations (CSOs) and rightwinged development theorists.

\section{Advantages of Participatory Development}

\subsection{The knowledge value of PD}

As far as PD is seen as an approach to include local peoples in development initiatives that will ultimately impact on their lives, there is constantly the need to generate local knowledges of their circumstances (Mohan, 2001; Chambers, 1997; Shah \& Baporikar, 2012). Thus, proponents of PD contend that it is the reality of the poor that counts as it concerns understandings of the good life and their livelihoods. They suggest that PD overturns the professional biases and topdown models that have characterised development thus far. In this thinking, development practitioners must continually aim to give up their preconceptions about knowledge of the circumstances of the poor and allow the latter to determine their development path because they are the experts with the relevant knowledge needed for their progress. For instance, Chambers (1995) argues that a correct poverty analysis cannot just be reduced to income levels but must also incorporate non-tangible aspects of life such as leisure and happiness amongst other things. This thinking is corroborated by Shah and Baporikar (2012) who point out that although development presupposes macroeconomic and financial considerations, it goes beyond the latter to include human and social aspects. Hence, a true PD seems to be the invaluable way to achieve this since it does not only reverse the prejudices that have side-lined and isolated the poor (Mohan, 2001) but also allows communities to develop their unique wealth of knowledge and capability to ascertain and solve their problems. Indeed, the summons to consider the realities and knowledges of the poor in development processes suggests ethical injunctions since the idea of a transfer of power to 'local experts in development' presupposes that poor people have been deprived of their abilities to decide on what is good for them.

\subsection{Participation enhances local peoples' ability to exploit their own assets}

$\mathrm{PD}$, understood as a move away from top-down approaches, takes as its point of depature that the human and social capital within societies can be exploited such that members of such communities are able to achieve development on their own terms and at their own pace. This assets-based perception of communities claims that no matter how poor people are; they possess capacities, assets and energies that can contribute immensely to building a sustainable quality of life (Schenck, Nel \& Louw, 2010: 6). Participatory initiatives, thus, that have attempted exploiting local peoples capacities include Participatory Rural Appraisal (PRA), Farmer Participatory Research (FPR), and Participatory Action Research (PAR). Considering PRA as a model approach, Chambers (1994) contends that there was the need to move beyond Rapid Rural Appraisal (RRA) towards appreciating local realities when development practitioners and researchers engage with the poor and PRA was a good way to do this. Duraiappah, Roddy \& Parry, (2005) suggest that 
PRA assists researchers not only to learn about communities but also to develop relevant interventions for these communities. In the same vein, Alam and Ihsan (2012) point out that it is a way of cooperating with communities to investigate and evaluate constrains and prospects that impact on their circumstances, in order to make timely decisions regarding development projects.

\subsection{PD facilitates ownership of development}

A key characteristic of PD, and indeed its most important principle (Shah \& Baporikar, 2012), is that it is meant to create a sense of ownership for community members who partake in development initiatives. The assumption is that when the poor contribute their services, resources, ideas to a project, no matter how little this may be, it makes them to feel a sense of responsibility for and control over that development initiative (Bessette, 2004; Shah \& Baporikar, 2012; FAO, 1991). The involvement of community members, say, in taking turns to operate a borehole water project in the community or to pay a small token for mosquito nets donated by an INGO creates a sense of responsibility and ownership. Similarly, when they are deliberately placed at the centre of projects instigated by external agencies, such undertakings have the potential to be empowering and sustainable in the long run since the community will own the results that will be produced (UNDP, 1997a; FAO, 1991). In effect, ownership in PD presupposes that the poor will not just be passive beneficiaries of development projects but will be active participants in researching, designing, decision-making, implementing and evaluating development initiatives intended to impact on their lives.

\section{The Downsides of Participatory Development}

Over the last two decades, PD has been castigated as the new autocracy in development. For instance, Cooke and Kothari (2001, as cited in de Campos Guimarães, 2009) propose what they call the 'tyrannies' of PD and ask whether so called participatory initiatives create situations where professionals dominate decision-making, whether group dynamics reinforce the power of elites, and whether participatory methods have dimmed other approaches that possess values that participation is unable to provide. Also, critiques of the concept have sometimes been divided into internal and external ones, the former stemming from proponents of the concept while the latter arises from antagonists. In general, however, major external criticisms of PD rally around issues of knowledge, community understandings and empowerment, as will be discussed below.

\subsection{The internal critique of $P D$}

Williams (2004) points out that the internal critique of PD takes its hinge mainly from the works of Chambers (see esp. 1994 \& 1995) particularly as it involves the shift from RRA to PRA. The invitation is for professionals, or 'uppers' governments, development practitioners, NGOs, among other role players to transfer power to 'lowers', the poor and marginalised, in order for development initiatives to be ultimately relevant and empowering to the latter (Chambers, 1994 \& 1995; Mohan \& Stokke, 2000; Botes \& van Rensburg, 2000). So called development professionals, then, must always strive to reorient themselves towards transforming PD. Although this call appears to be a noble one, it has been critiqued as being naïve in that it is an expectation from individuals that cannot be guaranteed, more or less a salvific invitation (Williams, 2004; Kapoor, 2002). The point is that this anticipated personal self-critique is placing too much trust in development professionals to altruistically change their attitudes towards the development process. Hence, it has been cast away as simplistic and a more strategic way for change to take place. Even though it may be granted that such calls appear to be inadequate for effective action, this discussion suggests that Chambers' (1995) bidding was a move towards a communicative ethics in PD, albeit an embryonic one. Indeed, his contention that PD must show equity in dialogue between the poor and so called development experts signals this. The latter is an idea that, perhaps, has not been taken seriously thus far in the evolution of the concept.

\subsection{The problem of establishing knowledge for development}

In opposition to the knowledge claims of PD, critics have argued that it is a problematique within the discourse. Following in what Neef (2003) refers to as myths of local knowledge, the questions that have been raised include whether knowledge claims from participatory initiatives are necessarily valid and reliable (Platteau, 2006; de Campos Guimarães, 2009) and whose knowledge is being generated (Cornwall, 2003; White, 1996). For example, Platteau (2006) argues that information being gathered from local contexts may be strategically distorted. He explains how so called homogenous 
communities may articulate biased preferences to suit the intentions of donors so that funding can be secured, a scenario that has been observed in decentralised projects in African countries such as Burkina Faso, Chad, Senegal and Malawi. The same question is asked of heterogeneous communities where the information being supplied is manipulated by local elites and is taken as valid information by donors and governments, as observed in the Indian Panchayats and other contexts within the developing world (Platteau, 2006).

More importantly for this discussion, however, is how the knowledge question measures up to a communicative ethics. If, for instance, we consider the issue of whose knowledge is being generated in development discourse we arrive at a point where issues of gender, class, ethnicity, etc. become crucial. Taking the gender question as an instance, the observation is that entrenched cultural and historical gender values may affect the discourses produced by women during participatory assemblies. Their submissions in these discursive contexts reveal a tendency to satisfy only their practical needs as the domesticated sex, thereby maintaining the status quo and limiting their potential for real empowerment (Cornwall, 2003; White, 1996). Also, in many contexts where PD has been applied, development agents and planners have often times maintained local inequalities, especially when discourses that they facilitate are dominated by dominant ethnic groups, local elites and men. Yet, an authentic development discourse cannot lay claim to being communicatively active and ethically sound if knowledges that are produced are biased and incomplete. Indeed, these irregularities fall short of the principles of a genuine dialogical process.

\subsection{The uncertainties of community}

A proper understanding of community is another long-standing issue within the PD discourse. Common practices have been to consider communities as enclosed within particular geographical locations and to view them as sites of high levels of social and human capital (Williams, 2004; Cleaver, 1999; de Campos Guimarães, 2009). Cleaver (1999), in what she refers to as 'myths of community', or what de Campos Guimarães, (2009) calls 'illusions of community', such narrow understandings do not only limit a description of rights and benefits, and create problems of inclusion and exclusion based on the defined entity, but also assume the geographical entity as centres of solidarity, harmony and resourcefulness.

Unproblematised understandings of community have also led to the concealment of powerful interests in societies. From a policy perspective, it has been argued that interests that reflect in policy documents about development of local communities usually amount to those expressed by powerful local elites who do not necessarily have the poor and marginalised at heart (Mohan \& Stokke. 2000; Platteau, 2006; Williams 2004; Bardhan, 2002). Indeed, the implication of this for a communicative ethics becomes paramount. For, if it is true that the concept community, as understood by local peoples, differs from how it is used by governments and other development organisations (Nelson \& Wright, 1995), then its understandings must continually be revisited and revised and the question continually asked about what who is defining community, and what this means for a PD that espouses authentic empowerment.

\subsection{Empowerment versus Efficiency}

The empowerment critique of PD is arguably the most grim that has been levelled against it. The question that is being raised is whether participatory initiatives have genuinely built up the capabilities of individuals, groups and communities. Duraiappah, Roddy and Parry (2005) posit that, although the poor are largely involved in the various stages of development, their inclusion does not always constitute authentic participation. Similarly, people's capabilities are hardly enhanced in such a manner as to enable them to chart the course of their destinies in collaboration with the government, NGOs and amongst other role playes.

\subsection{The means/ends analysis of $P D$}

The means/ends analysis of PD distinguishes between the instrumental and empowerment objectives of PD (Cleaver, 1999; de Campos Guimarães, 2009; Nelson \& Wright, 1995; Davids et al, 2009). The overarching point that is being raised is whether development practitioners have consciously or unconsciously limited the scope of PD by measuring its successes based on the efficiency of projects as opposed to considering empowerment as an end in PD in order to help poor and marginalised people to become enabled and thus take charge of their own lives and development. Cleaver (1999) observes how understanding PD in terms of projects treats of it as a narrow process. Project-styled initiatives imply clearly demarcated arrangements of activities with fixed budgets and timeframes. In most cases they are concerned with meeting people's practical needs as opposed to strategic ones. The result of this is that while poor and marginalised 
peoples may receive sewing machines and mosquito nets during a project, they ultimately will not be enabled for development in a concrete sense. If projects are about meeting targets that do not take into consideration the non-project aspects of people's lives (Cleaver, 1999, Nelson \& Wright, 1995), then PD ought to begin to reconstruct itself as a reliable instrument for people empowerment.

\subsection{Decentralisation as local empowerment of people}

A more recent issue that has characterised the PD discourse is that of decentralisation. Understood as full or partial relinquishing of authority either through devolution, deconcentration or complete decentralisation, it has been noted that it is a useful way of dialoguing with and meeting people at grassroots level (Mohan \& Stokke, 2000, Conyers 1986 and Bergh, 2004. In the words of Bergh, (2004: 781), "democratic decentralisation emphasises the linkages between the state and the people, and consequently between decentralisation and participation"; there is, therefore, a "symbiotic relationship" between the two. The point is that the closer the institutionalised state is to the people the more likely they will participate in decision processes that affect them.

Despite the foregoing, the shortcomings of decentralisation have continually been brought to the limelight. For instance, technical and administrative services at the local level may be weak and accountability from corrupt officials may be problematic, this resulting in a 'decentralisation of corruption' (Bergh, 2004: 782). Also, decentralised institutions to the local level may be prone to "elite capture" where public goods do not reach the poor because these have been captured by local power holders, raising the question of whether corruption and unaccountability are greater at the national or local level (Bardhan, 2002: 188). Indeed, Nelson and Wright (1995) argue that decentralisation could in reality be continued centralisation.

\subsection{Participatory development depoliticised}

Insofar as the local is understood as a site for progress it must also be seen as a location for conflict (White, 1996; Mohan, 2001). Because people cannot be considered merely as passive recipients of the dividends of development, analyses of local participation must include a political component. The common view of PD as a smooth, apolitical process, does not only indicate that development practitioners have many times over-reported the successes of PD (World Bank, 2012; Duraiappah, Roddy \& Parry, 2005) but has also ensured that the realities of power struggles have been undermined and distorted at the local level (Mohan, 2001). Questions that have been raised, for instance, include whether enabling people economically excludes building political capabilities and if the right to development does not involve the right to be part of political processes (Williams, 2004; Cornwall \& Brock, 2006).

Distinguishing between revised neoliberalism and post-Marxism, Mohan and Stokke (2000) observe how power has been nuanced in both ideologies. While empowerment of local peoples can be achieved in the former, without necessarily affecting the influence of the powerful, the latter views the empowerment of poor people "as a structural transformation of economic and political relations towards a radically democratised society" (249). Essentialising and romanticising the local becomes a problematique since a correct analysis of the politics of the local would reveal that power politics at this level is underplayed. As such, the relationship between consensus and difference (Nelson \& Wright, 1995), spaces for participation and political action (de Campos Guimarães, 2009; Mohan \& Stokke, 2000; Kapoor, 2002; Cornwall \& Brock, 2006), roles and influence of the state, NGOs, IDAs, and civil society in development (Cleaver, 1999; World Bank, 2012; Williams, 2004; Davids et al, 2009) need to be taken seriously for PD to be duly politically scrutinised.

From the foregoing discussion, the query that comes to the fore is what does the future hold for PD? Can the concept free itself from the vote of no confidence that has been passed on it and prove its worth for development thinking and the enablement of peoples? The following section of this discussion, which tends to be more of a reflective effort, urges authentic dialogue with the poor and marginalised to be placed at the heart of PD, and indeed at the centre of development practice as a whole. This is possible through situating PD within a communicative ethics.

\section{Authentic Dialoguing for Development: Advocating a Communicative Ethics}

The foregoing assessment creates a scenario of pessimism around the PD discourse. Yet, optimism can be garnered from the existing scenario. For, although the general impression among critics is that the concept has lost both its usefulness and reliability as an instrument of empowerment, these critics may not be entirely opposed to PD if it helps people to become truly empowered. Indeed, this discussion argues that to throw away the baby with the bath water is counterproductive since participatory initiatives have sometimes been successful in some contexts in the developing 
world. In the latter regard, Baiocchi's (2003) observation of local participatory budgeting in Porto Alegre, Brazil, Ostrom's (2000) example of farmer organisation for effective irrigation in Nepal and Wade's (1987) instance of irrigated villages in South India are instructive. In light of this, the following reflective questions can be asked: What would empowerment mean if a communicative ethics is placed at the centre of PD? In what ways can one ensure that dialoguing for development increases people's capabilities? In short, to follow de Campos Guimarães (2009), what would count as 'good enough participation' today? The discussion below addresses these questions by taking up issues of citizenship, empowerment, and partnership as germane to rediscovering PD.

\subsection{Reconstructing citizenship for empowerment}

From the communicative action framework, especially as highlighted in the principles for genuine participation, the need for an appropriate conception of citizenship is put on the pedestal. This is because active citizenship is critical for empowerment to be achieved. An observation is that the discourse on PD, in its theoretical and practical bearings, has neglected this aspect especially as it relates to enabling local people for political action. Thus, a reconstitution of participation requires promoting citizenship as a genuine and transformative approach to development (Croft \& Beresford, 1996; Hickey \& Mohan, 2005; de Campos Guimarães, 2009; Williams, 2004; Mohan, 2001). The relevance of this is detectable, for instance, in scenarios where citizens would have the right to hold to account those who have summoned them to participate in development in the first instance (de Campos Guimarães, 2009). Further in this thinking, citizenship takes a radicalised path when it breaks out of an undue fixation on the local towards an engagement with broader structures of injustice, marginalisation and subjugation (Mohan \& Stokke, 2000). Through communicating actively and ethically for development, citizens partake in discourse processes that affect their lives and well-being in a concrete way.

The appreciation of the Habermasian model of communicative action resonates with his notion of deliberative democracy (Kapoor, 2002). Within this agenda, a decentralised politics does not necessarily imply a naïve movement of power from uppers to lowers but presupposes participation as an avenue for ongoing, open-ended, dialogical processes among all actors in development. All stakeholders, therefore, come to the table of discussion, professionals and the poor alike, based on communicative intentionality such that their interventions in the lives of the latter not only address issues of power, justice, the politics of gender and equality but that the discourse is ultimately directed at their authentic enablement. This understanding of citizenship from below helps to include local people in the dialogue for development, especially those who would otherwise have been excluded such as women, the urban and rural poor, and those whose contributions may have been considered insignificant. The first principle of authentic dialogue, then, is met as no one with the competence to speak and act is left out of the discourse for development and no one takes precedence over the other since the dialogue is not strategic but always communicative (Habermas, 1990; McCarthy, 1978). Authentic dialogue, in such a scenario, is free, inclusive, challenging and on-going, and is directed towards consensus-building and negotiating terms of collaboration and involvement (Shah, 1997, as cited in Mohan, 2001). Citizenship reconstructed in this way allows for a 'new political imaginary' of participation (Mohan \& Stokke, 2000) that will see PD transcending its present project-styled development. Governments and other development practitioners, then, do not just work towards legitimising their interventions in the lives of the poor and marginalised but are concerned with developing an active citizenry in the longer term.

\subsection{PD as genuine enablement of people}

A PD focussed on genuinely addressing both the practical and strategic needs of the poor is conceivable through the continual expansion of spaces for participation and empowerment. In this thinking, the empowering and transformative nature of participation works in a dual sense: as a means of challenging existing initiatives of development that focus on practical needs and do not pay attention to long term strategic interests; and as an avenue for enablement, where the building up of people's capabilities are the focus of development strategies (Duraiappah, Roddy \& Parry, 2005). A process of dialogue hinged on communicative ethics espouses a politics of recognition (Taylor, 1992; Hickey \& Mohan, 2005). This implies recognising the humanity of poor and marginalised peoples and accepting that they have a right to holistic development. With the belief that the rhetoric of empowerment has lost its radicalism, calls have been made for this value to be regained, this linked closely to the Freirean conception of conscientisation (Mohan \& Stokke, 2000; Cleaver. 1999). Enablement in this regard would entail developing initiatives to meet poor and marginalised people's day to day needs alongside continuous consciousness-raising about their socio-economic and socio-political realities. Reconstructing empowerment means building people's capabilities in a concrete, honest and sustainable way (Williams, 2004). Duraiappah, Roddy and Parry $(2005,23)$ refer to the notion of 'appreciative inquiry' as having the ability to "assist 
groups and communities to understand their capabilities and develop positive visions for their future". Genuine empowerment, thus understood, cannot be located in project cycles that are time-constrained but is a continuous, deliberate, communicatively active, and ethical process.

The World Bank (2012) notes that while community participation have had some successes with initiatives in education and health it has not had equivalent progress in reducing poverty or building capacity for collective action. Spaces for empowerment of people at the local level must, then, continue to be created. These spaces would not only allow for discussions around transparency, accountability, partnership, sharing of power, and cooperation (Duraiappah, Roddy \& Parry, 2005) but would also facilitate discourses around rights, responsibilities, class, gender and ethnicity. Within these spaces, a political analysis would lead to an engagement with all stakeholders in development (Williams, 2004), and how each one is important in the empowering process. As Shah and Baporikar (2012) suggest, the challenge for PD is how to locate the marginalised, give them a voice, and enable them with skill and knowledge. Unlike the view of Chambers (1994) where empowerment of poor peoples requires a reversal and change of roles between uppers and lowers, communicative ethics proposes that the uppers and lowers get into communicative action for development. In this regard, top-down, externally imposed project-styled development becomes an imbalance of power (Bleckley, 2008) and this can be corrected through authentic dialogue based on a communicative ethics. Power is, thus, constantly negotiated and renegotiated, debated and redebated, but always in the direction of authentically enabling people. Indeed, Williams' (2004) and Mohan's (2001) suggestions that empowerment should not be seen as a once-for-all movement of power in a hierarchical sense but should rather be located within longer-term political struggles is instructive in this case. Hence, it is not so much about just transferring power but more about using power to spur development collectively.

\subsection{A partnership for progress: Role of the state}

An important question in the discourse of development is whether PD can, or should be practiced outside of the confines of the state and its machineries, or whether it is more rewarding to have all stakeholders play equal roles for progress (Cleaver, 1999; Mohan \& Stoke, 2000; Cornwall, 2003; World Bank, 2012). Mkandawire (2001) observes that development ideology must be complemented with structure, whereby states with ideologies have real capacity to tailor political, technical, institutional and administrative resources effectively towards economic and social development. It is debatable that in Africa the latter has been achieved in places like South Africa, Madagascar, and Botswana to an extent. In the South African context, for instance, the introduction of programmes like the Reconstruction and Development Programme (RDP), the Growth, Employment and Redistribution (GEAR), the Land Reform for Agricultural Development (LRAD), etc. were all proclaimed as participatory initiatives aimed at addressing people's wellbeing and were empowering (Triegaardt, 2009). Nonetheless, while the GEAR policy was argued to be neoliberal in its orientation, the LRAD was shown to be beset with questions of who gets land based on productive capabilities (James, 2010), and these policies were critiqued as incongruent with PD. In other contexts, the bureaucratic and unresponsive nature of the state to the conditions of the poor and marginalized may be a stumbling block to PD. For instance, the continual debates about the role and impact of the informal sector on national economies exemplifies how states continually shut poor people out of the discourse for development (de Soto, 1989; Meagher, 1995: 268). If it is granted that the deprived ought to be part of the development process, then it is important that governments begin to communicate actively and ethically with them and address issues of neglect, unsustainable livelihoods and diminishing well-beings (de Soto, 1989). This would entail combining the assets-based understandings of development with broader, state-led initiatives to combat deprivation in local communities.

\subsection{A challenge to donor agencies}

Nelson and Wright $(1995,195)$ refer to what they call the 'paradox of aid agencies'. Their point is that while these agencies proclaim the value of power sharing and empowerment of peoples, they rarely incorporate this as a clear-cut objective in PD; 'they exert influence while desiring to build up local self-capacity and participation'. This is clearly exemplified in the relationship between the World Bank, the International Monetary Fund (IMF), the World Trade Organisation (WTO), bilateral donors and individual countries and local communities. The continued struggle for power between these international bodies and individual countries, not least sustained by foreign aid and its conditionalities, debt, voting rights, etc. indicates that PD is still far from ensuring empowerment, even at national and global levels (Williams, 2000; Gordon, 2006, Thomas, 2004; Moss, 2011). If the developing world is going to be able to achieve sustainable social, political and economic development, the present nature of international relations must be overhauled to allow for a communicative ethics. An authentic PD built on a communicative action, then, would entail IFIs and other 
global development institutions getting into genuine dialogue with states, citizens, CSOs, and communities while they all work together for development, spurred on by political will and concern for genuine enablement of people. This bespeaks an ethics of engagement and ensures sustainable development, without which deprived peoples will continue to grope in the dark for their development and PD will remain an empty concept.

\subsection{Local people: the most important resources for PD}

Development cannot work if people do not own it. This is an essential point to be noted especially as understood from the social development model (Midgley, 1998; Patel 2005). To this end, it is critical that people be actively involved in participation in decision making on issues that affect them. However, anecdotal evidence points towards a citizenry that is disengaged from development processes that impact on them. This is particularly true of citizens in developing countries particularly in Africa. This kind of attitude is surely regressive to development and does not share the vision of a communicative ethics. It also does not bespeak a citizenry that is driven towards acting communicatively, responsibly and willing to own the development process (Shah \& Baporikar, 2012). Hence, ways to incorporate people into development processes must continue to be sought to ensure that the development process is ultimately owned by citizens. This may be achieved by a continual political sensitisation of local populations. In effect, without an authentic, shared vision for economic, political and social development by national governments and the corresponding contribution by citizens and development agents, participation will continue to be no good to development.

\section{Conclusion}

Dialoguing for development is about a true effort to impact on the realities and well-being of all peoples. This process requires a communicative ethics whereby a fusion of horizons should always be the end point of genuine discourse. Hence, the discussion situated PD within the framework of communicative action. It argued that PD on the one hand ought to be about honest engagement with deprived peoples and aiming to empower them authentically and on the other hand about genuine communication among present power holders themselves including governments, IFIs, IDAs, INGOs among other role players. The discussion argued that communicative ethics is an essentiality for PD as it proposes a framework to integrate the poor and the marginalised into the developmental process effectively. As long as a communicative ethics becomes the focus in PD, both at the micro and macro levels, then the impact of the latter on the empowerment of poor and marginalised people is conceivable. For, as Bleckley (2008: 34) urges, "increasing participation at all levels requires constant discourse, founded in truly balanced power, and the building of collective knowledge at every phase of the development effort". The participation component of development appears to be stagnated and this paper argues that, this is where a communicative ethics is necessitated in order to instigate a process of rediscovery.

\section{References}

Baiocchi, G. (2003). Emergent public spheres: Talking politics in participatory governance. American Sociological Review, 68, 52-74.

Bardhan, P. (2002). Decentralization of governance and development. Economic Perspectives, 16, 185-205.

Bergh, S. (2004). Democratic decentralisation and local participation: A review of recent research. Development in Practice, 14, 780-790.

Bessette, G. (2004). Involving the community: A guide to participatory development communication, Malaysia/Canada: Southbound and International Development Research Centre.

Bleckley, D. (2008). Assessing participatory development processes through knowledge building. SPNA Review, 4, 21-36.

Botes, L., \& van Rensburg, D. (2000). Community participation in development: Nine plagues and twelve commandments. Oxford University Press and Community Development Journal, 35, 41-58.

Brohman, J. (1995). Universalism, eurocentrism, and ideological bias in development studies: From modernization to neo-liberalism. Third World Quarterly, 16, 121-140.

Chambers, R. (1994). Paradigm shifts and the practice of participatory research and development. Institute of Development Studies, Working Paper.

Chambers, R. (1995). Poverty and livelihoods: Whose reality counts? Environment and Urbanization, 7, 173-204.

Chambers, R. (1997). Whose reality counts: Putting the first last, London: Intermediate Technology Publications.

Cleaver, F. (1999). Paradoxes of participation: Questioning participatory approaches to development. International Development, 11, $597-612$

Cornwall, A. (2003). Whose voices? Whose choices? Reflections on gender and participatory development. World Development, 31, 1325-1342.

Cornwall, A., \& Brock, K. (2006). What do buzzwords do for development policy? A critical look at 'participation', 'empowerment' and 
'poverty reduction'. Third World Quarterly, 26, 1043-1060.

Croft, S., \& Beresford, P. (1999). The Politics of participation. In D. Taylor (Ed.). Critical social policy: A reader. London: Sage, 175-198.

Davids, I., Theron, F., \& Maphunye, K. T. (2009). Participatory development in South Africa. A development management perspective (2nd ed.). Pretoria: Van Schaik Publishers.

De Campos Guimarães, J. P. (2009). Participatory approaches to rural development and rural poverty alleviation. Institute of Social Studies, Working paper.

De Soto, H. (1989). The other path: The invisible revolution in the third world. J. Abbott (Trans.). Harper and Row.

Duraiappah, A.K., Roddy, P., \& Parry, J. (2005). Have participatory approaches increased capabilities? International Institute for Sustainable Development, 1-31.

Escobar, A. (1995). The making and unmaking of the third world through development. In R. Majid \& V. Bawtree (Eds.). The PostDevelopment Reader, London: Zed, 85 - 93.

FAO (1991). Plan of action for people's participation in rural development. Twenty-sixth

session FAO conference. Rome, 9-28 November 1991.

Gordon, R. (2006). Sub-Saharan Africa and the brave new world of the WTO: Multilateral trade regime. Review of International Studies, $26,568-72$.

Habermas, J. (1990). Moral consciousness and communicative action. C. Lenhardt \& S. Nicholsen (Trans.). Cambridge: MIT Press.

Hickey, S., \& Mohan, G. (2005). Relocating participation within a radical politics of development. Development and Change, 36, $237-262$.

James, D. (2010). Doing business with a development ethic. In B. Freund \& H. Witt (Eds.). Development dilemmas in post-apartheid South Africa, Kwazulu-Natal: Kwazulu-Natal Press, 220-247.

Jennings, R. (2000). Participatory development as new paradigm: The transition of development professionalism', Washington DC.

Kapoor, I. (2002). The devil's in the theory: A critical assessment of Robert Chamber' work on participatory development. Third World Quarterly, 23, 101-117.

Lane, J. (1995). Non-governmental organisations and participatory development: The concept in theory versus the concept in practice. In N. Nelson \& S. Wright (Eds.). Power and participatory development: Theory and practice, London: Intermediate Technology Publications, 181-191.

McCarthy, T. (1978). The critical theory of Jürgen Habermas. Cambridge: MIT Press.

Meagher, K. (1995). Crisis, informalization and the urban informal sector in sub-Saharan Africa. Development and Change, 26, $259-284$.

Midgley, J. (1998). Social development and social welfare: South Africa in an international context. Social Work/Maatskaplike Werk, 34, 90-98.

Mkandawire, T. (2001). Thinking about developmental states in Africa. Cambridge Journal of Economics, 25, 23-49.

Mohan, G. (2001). Participatory development. In D. Vandana \& P. Rob (Eds.). The Arnold companion to development studies, London: Hodder, $49-54$.

Mohan, G., \& Stokke, K. (2000). Participatory development and empowerment: The dangers of localism. Third World Quarterly, 21, 247268.

Moss, T. (2011). African development: making sense of the issues and actors, Colorado/London: Lynne Rienner.

Neef, A. (2003). Participatory approaches under scrutiny: Will they have a future? International Agriculture, 42, 489-497.

Nelson, N., \& Wright, S. (1995). Participation and Power. In N. Nelson \& S. Wright (Eds.). Power and participatory development: Theory and practice, London: Intermediate Technology Publications, 1-19.

Patel, L. (2005). Social welfare and social development. Cape Town: Oxford University Press.

Pierterse, J. N. (2000). After post-development. Third World Quarterly, 21, 175-91.

Platteau, J. (2006). Pitfalls of participatory development. In Participatory governance and the millennium development goals. New York: United Nations, 1-47.

Schenck, R., Nel, H., \& Louw, H. (2010). Introduction to participatory community practice. UNISA: Unisa Press.

Shah, A., \& Baporikar, N. (2012). Participatory approach to development in Pakistan. Economic and Social Studies, 2, 111 - 141.

Taylor, C. (1992). The Politics of Recognition. In A. Gutmann (Ed.). Multiculturalism, Princeton: University Press.

Thomas, C. (2004). The international financial institutions relations with Africa: Insights from the issue of representation and voice. In I.

Taylor \& P. Williams (Eds.). Africa in international politics: External involvement on the continent, London; New York: Routledge.

Triegaardt, J. D. (2009). Pursuing a social development agenda in the context of development: A South African perspective. International Social Work, 45, 1-10

UNDP (1997a). Empowering people: A guide to participation. United nations development programme, Washington DC.

White, S. (1996). Depoliticising development: The uses and abuses of participation. Development in Practice, 6, 6-15

Williams, D. (2000). Aid and sovereignty: Quasi-states and international financial institutions. International Studies, 26, 568-72.

Williams, G. (2004). Evaluating participatory development: Tyranny, power, and (re) politicisation', Third World Quarterly, 25, 557-578.

World Bank (2012, November 14). When do participatory development projects work? www.worldbank.org. Accessed 12 June, 2013. 